\title{
BERGERAK AKTIF DAN CERIA PADA MASA PANDEMI COVID-19 DENGAN PERMAINAN PICKLEBALL
}

\author{
Muhammad Iqbal Jauhar Hanim, S.Pd., M.Or27 \\ (Universitas Negeri Yogyakarta)
}

"Perasaan ceria dan aktivitas gerak berperan penting di masa pandemi, salah satu pilihan yang ditawarkan yaitu bermain pickleball"

Keceriaan menjadi sesuatu yang penting di tengah
pandemi covid-19 yang belum terlihat akan segera berakhir. Ceria dapat disebut dengan perasaan riang gembira, bahagia, sejenak melupakan beban maupun tugas yang rutin dikerjakan setiap hari. Ceria dapat ditandai dengan menghibur diri sendiri dan juga orang lain di lingkungan sekitar. Perasaan ceria merupakan salah satu dari fungsi rekreasi. Meskipun terlihat sederhana, namun perasaan ceria besar manfaatnya dalam kehidupan ini. Perasaan ceria membuat seseorang refresh dan terhindar dari kecemasan dalam mengerjakan tugas sehari-harinya. Perasaan ceria ini memberi manfaat apabila masih dalam takaran yang

27Penulis lahir di Mojokerto, 05 Maret 1993, penulis merupakan fresh graduate S2 Ilmu Keolahragaan di Universitas Negeri Yogyakarta. Penulis menyelesaikan gelar Sarjana Pendidikan Jasmani dan Keolahragaan di Universitas Negeri Malang (2015), sedangkan gelar Magister Ilmu Keolahragaan diselesaikan di Universitas Negeri Yogyakarta (2020). 
wajar dan tidak berlebihan. Keceriaan yang berlebihan membuat seseorang menjadi kehilangan arti hidupnya akibat melupakan kesibukannya dan kewajiban melakukan pekerjaan.

Kita mungkin sudah mengetahui bahwa suasana hati diatur oleh hormon di dalam tubuh manusia. Hormon merupakan senyawa kimia dalam tubuh yang merupakan hasil dari produksi kelenjar di seluruh bagian tubuh manusia. Hormon didistribusikan ke seluruh tubuh melalui aliran darah, juga bertindak sebagai pembawa pesan memiliki peran penting di dalam tubuh manusia. Dari sekian banyak fungsi hormon bagi tubuh manusia, terdapat fungsi penting berhubungan dengan keceriaan yaitu berperan mengatur suasana hati. Beberapa jenis hormon diketahui membantu meningkatkan perasaan positif, dalam hal ini bahagia, senang, dan ceria. Beberapa hormon tersebut diantaranya yaitu dopamin, serotonin, oksitosin, dan endorfin. (1) Hormon dopamin juga dikenal sebagai hormon "perasaan baik". Dopamin merupakan hormon dan neurotransmitter yang merupakan bagian penting sistem penghargaan otak. Dopamin dapat dikaitkan dengan sensasi yang menyenangkan. (2) Hormon serotonin dikenal juga sebagai neurotransmitter yang memiliki peran mengatur suasana hati. Aktivitas lain yang berpengaruh terhadap hormon serotonin yaitu tidur, nafsu makan, pencernaan, kemampuan belajar, dan ingatan. (3) Hormon oksitosin dapat juga disebut sebagai hormon cinta. Hormon ini berperan penting dalam persalinan, menyusui, dan ikatan orangtua-anak yang erat. Hormon ini juga dapat membantu meningkatkan kepercayaan, empati, dan ikatan dalam hubungan, dan kadar oksitosin umumnya 
dapat meningkat dengan rangsangan fisik seperti ciuman, pelukan, dan hubungan dekat. (4) Hormon endorfin merupakan pereda nyeri alami tubuh. Hormon ini diproduksi tubuh sebagai respon terhadap stress atau ketidaknyamanan yang terjadi. Kadar endorfin cenderung meningkat ketika melakukan aktivitas yang menimbulkan perasaan memuaskan seperti makanan lezat dan berolahraga.

Selain keceriaan, sesuatu lain yang dibutuhkan di masa pandemi yaitu bergerak aktif. Berdasarkan data dari Riset Kesehatan Dasar, pada tahun 2013 rata-rata masyarakat Indonesia yang kurang melakukan aktivitas fisik mencapai $26 \%$, dan meningkat menjadi $33 \%$ pada tahun 2018. Masa pandemi covid-19, persentasi ini diprediksi akan meningkat, karena banyak sesuatu yang dilakukan dari rumah sehingga membatasi kegiatan masyarakat. Apabila seseorang abai terhadap gerak aktif sehari-hari, maka resiko penyakit tidak menular akan mengancam kesehatan kita, seperti penyakit stroke, jantung, dan diabetes. Penyakit tidak menular ini menjadi penyebab $63 \%$ kematian di seluruh dunia atau dapat dijelaskan mempu membunuh 36 juta jiwa setiap tahunnya. Dengan menerapkan gerak aktif, berarti memberikan kesempatan pada sistem tubuh manusia seperti rangka, sendi, dan otot agar dapat berfungsi dengan baik. Di Indonesia, Pemerintah menghimbau kepada masyarakat untuk melaksanakan GERMAS. GERMAS merupakan akronim dari Gerakan Masyarakat Hidup Sehat. Program GERMAS diharapkan meningkatkan kesadaran masyarakat tentang pentingnya bergerak aktif dan menghindari gaya hidup sedentari. Gaya hidup sedentari (sedentary lifestle) dalam 
dunia kesehatan berarti kasus malas bergerak. Bergerak aktif juga bermanfaat untuk menjaga bentuk penampilan yang prima.

Sinergi antara keceriaan dan bergerak aktif dapat dikemas menjadi sebuah permainan yang bersifat rekreatif dan aman dilakukan selama masa pandemi covid-19. Beberapa langkah yang dapat dilakukan agar permainan menjadi aman dilakukan selama masa pandemi yaitu (1) wajib menjaga jarak sehingga tidak menimbulkan kerumunan, (2) sterilisasi alat yang digunakan dalam permainan dengan cairan disinfektan, seperti pada bola, raket, dan sebagainya, (3) memakai masker bagi setiap pemain, (4) mencuci tangan dengan sabun pada air yang mengalir setiap dan setelah pertandingan, (5) permainan dilakukan di dalam maupun luar ruangan dengan sirkulasi udara dan pencahayaan yang memadai. Permainan net dinilai sebagai permainan yang aman dilakukan selama masa pandemi covid-19, karena tidak menimbulkan kerumunan dan dapat menjaga jarak. Hal tersebut berlaku bagi pemain yang sehat dan memainkannya dengan orang dengan kondisi yang sehat juga. Beberapa contoh permainan net yaitu bola voli, tenis, tenis meja, sepak takraw, bulu tangkis, dan voli pantai. Tujuan dari permainan net yaitu mengarahkan bola ke daerah lawan sehingga lawan tidak dapat mengembalikan bola dan pemain dihitung mendapatkan poin. Kemenangan tiap set dihitung apabila jumlah poin pemain telah mencapai poin tertentu sesuai dengan yang telah ditetapkan. Seperti pada permainan bulu tangkis, kemenangan tiap set dihitung apabila mencapai poin 21 dan unggul 2 poin 
dari lawan, sementara pada permainan tenis meja yaitu poin 11 untuk setiap setnya.

Dewasa ini muncul beberapa permainan modifikasi net yang dimainkan secara single maupun double. Permainan seperti Teqball yang pertama kali dimainkan pada tahun 2014. Teqball adalah olahraga net yang menyerupai tenis meja, namun menggunakan peraturan seperti sepak bola yaitu pemain dapat menggunakan seluruh anggota badan kecuali tangan. Teqball dimainkan pada meja melengkung dan menggunakan bola yang digunakan dalam permainan sepak bola. Penulis menyebutnya dengan modifikasi tenis meja dengan kaki. Permainan modifikasi net lainnya yaitu footvolley. Footvolley pertama kali dimainkan pada tahun 1965. Pada permainan ini pemain tidak boleh menggunakan tangannya untuk mengarahkan bola ke daerah lawan. Permainan modifikasi net lainnya yang penulis fokuskan dalam artikel ini yaitu pickleball. Permainan ini merupakan gabungan dari tiga unsur cabang olahraga yaitu tenis meja, tenis lapangan, dan bulu tangkis. Hal tersebut dikarenakan pada permainan pickleball, dimensi lapangannya yaitu sebesar lapangan bulu tangkis meskipun dapat dimainkan secara indoor maupun outdoor layaknya permainan tenis, jaringnya mirip jaring lapangan tenis, dan paddle yang digunakan mirip dengan bet permainan tenis meja. Permainan pickleball yang populer, mulai dimainkan di Indonesia didukung dengan beberapa toko olahraga maupun distributor melayani penjualan online peralatan yang digunakan dalam pickleball seperti paddle, bola, dan jaringnya. 


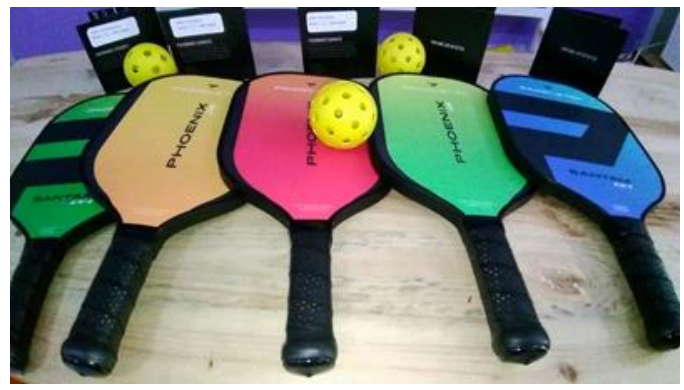

Gambar 1. Paddle dan Bola digunakan dalam Permainan Pickleball

Tinggi net yaitu $86 \mathrm{~cm}$ dari tanah. Lapangan pickleball dan bulu tangkis memiliki ukuran yang sama, namun pada lapangan pickleball jaring net diturunkan ke tanah hingga tinggi net yaitu mencapai 34 inchi dari tanah. Paddle dirancang khusus dengan ukuran yang lebih kecil dibandingkan raket tenis, namun paddle berukuran lebih besar dari ukuran bet tenis meja. Paddle berbahan fiber yang tidak mudah rusak. Apabila dibandingkan dengan raket badminton dan raket tenis, paddle lebih hemat karena tidak diperlukan biaya untuk mengganti dan memasang senar raket. Bola yang digunakan dalam permainan pickleball terbuat dari plastik dengan kualitas baik sehingga awet. Bentuk bola ini yaitu berlubang sehingga membuat laju bola lebih lambat.

Permainan ini dapat dimainkan dengan menggunakan paddle untuk memukul bola. Setiap pemain harus memegang 1 buah paddle untuk dapat memukul bola. Untuk memulai pertandingan dapat dilakukan service dengan posisi bola di bawah pusar atau lazim disebut service bawah. Pada mulanya, masingmasing pemain berdiri di belakang garis dasar sisi kanan lapangan untuk melakukan service diagonal. Bola dipukul 
dengan paddle secara diagonal ke zona service lawan. Pelanggaran dalam melakukan service yaitu apabila pemukul memukul bola di atas ketinggian pinggang maupun apabila bola memantul dari tanah. Selanjutnya setelah melakukan service, pemain lawan bertugas mengembalikan bola ke daerah pemukul. Rally terus berlanjut sampai salah seorang pemain tidak dapat mengembalikan bola ke daerah lawan, atau gagal mengikuti ketentuan tertentu. Service hanya diberikan bagi pemain yang mendapatkan poin. Service over terjadi apabila server kehilangan poin. Pada kondisi normal, satu set permainan pickleball berakhir di angka 11 dan unggul 2 poin dari lawannya. Apabila skor imbang di angka 10-10, permainan dilanjutkan sampai salah satu pemain unggul 2 poin dari lawannya. Selanjutnya satu set berakhir dan pemain dapat beristirahat untuk melanjutkan set berikutnya.

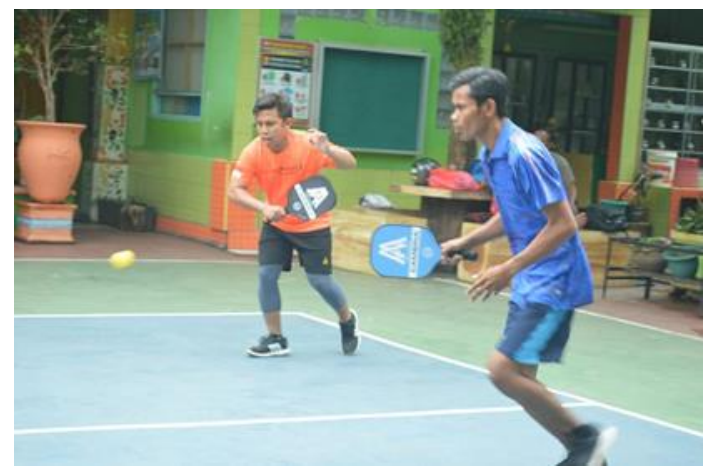

Gambar 2. Gerak Aktif dan Ceria pada Masa Pandemi Covid-19 dengan Pickleball

Karakteristik permainan pickleball yaitu merupakan permainan menyenangkan karena mudah dimainkan oleh orang yang tidak memiliki dasar motorik yang baik. Ini berarti permainan pickleball dapat dimainkan oleh 
anak-anak hingga manula dengan waktu yang lama, karena lapangan pickleball berukuran lebih kecil dibandingkan luas lapangan tenis. Hal penting dalam permainan pickleball yaitu pemain tidak dibolehkan menginjak garis kotak depan dan ketika permainan berlangsung, semua pukulan harus dilakukan di belakang kotak depan. Permainan pickleball dapat dimainkan dalam ruangan maupun di luar ruangan. Bermain pickleball dengan komunitas, rekan kerja, maupun keluarga merupakan kegiatan yang asyik agar ceria dan bergerak aktif Tetap mematuhi protokol kesehatan di masa pandemi merupakan cara cerdas untuk berolahraga dengan aman. 